\title{
Environmental influences on familial discordance of phenotype in people with homocystinuria: a case report Francois Maillot ${ }^{* 1,2}$, Jan P Kraus ${ }^{3}$ and Philip J Lee ${ }^{1}$
}

\author{
Address: ${ }^{1}$ Charles Dent Metabolic Unit, The National Hospital for Neurology and Neurosurgery, Queen Square, London, UK, ${ }^{2} \mathrm{CHRU}$ de Tours, \\ Service de Médecine Interne et Nutrition, Tours, France and ${ }^{3}$ DNA Diagnostics Laboratory, University of Colorado at Denver and Health Sciences \\ Center, Aurora, USA \\ Email: Francois Maillot* - maillot@med.univ-tours.fr; Jan P Kraus - Jan.Kraus@uchs.edu; Philip J Lee - philip.lee@uclh.nhs.uk \\ * Corresponding author
}

Published: 20 April 2008

Journal of Medical Case Reports 2008, 2:113 doi:10.1 186/1752-1947-2-113
Received: 23 August 2007

Accepted: 20 April 2008

This article is available from: http://www.jmedicalcasereports.com/content/2/1/1 13

(c) 2008 Maillot et al; licensee BioMed Central Ltd.

This is an Open Access article distributed under the terms of the Creative Commons Attribution License (http://creativecommons.org/licenses/by/2.0), which permits unrestricted use, distribution, and reproduction in any medium, provided the original work is properly cited.

\begin{abstract}
Introduction: Non-heritable factors may have an influence on the clinical expression of monogenic inherited metabolic diseases.

Case presentation: This is a case report of a man whose mother had been diagnosed late in childhood with pyridoxine responsive homocystinuria with lens dislocation and neurodevelopmental delay. These severe complications were not observed in her son who was pyridoxine unresponsive but who had been treated appropriately since early infancy.

Conclusion: The phenotype of people with homocystinuria can be discordant within a family, with variability in metabolic and clinical expression depending upon both the genotype and therapeutic interventions. Offspring of people with homocystinuria should be screened in early infancy and, if positive, treated appropriately whether they have pyridoxine responsive or unresponsive disease.
\end{abstract}

\section{Background}

Homocystinuria is an inherited recessive disorder due to cystathionine beta-synthase (CBS) deficiency, with a wide spectrum of clinical manifestations involving ocular lens dislocation, skeletal disproportion, osteoporosis, vascular thromboses and central nervous system dysfunction. We report a familial discordance of phenotype between a mother and her son, both affected with homocystinuria, to illustrate powerful environmental influences on the metabolic phenotype.

\section{Case presentation}

Our patient, born in 1986, was the second son of a woman who had had progressive loss of vision during the first 7 years of her life, related to bilateral dislocated lenses. She was diagnosed with homocystinuria when both lenses were surgically removed when she was 7 years old. Plasma free homocystine and methionine were 48 $\mu \mathrm{mol} / \mathrm{l}(N=0)$ and $670 \mu \mathrm{mol} / \mathrm{l}(N=19-25)$, respectively. She had moderate learning difficulties, a depressed sternum, pes cavus, high arched palate, fair skin with easily seen veins and signs of osteoporosis on spinal X-rays. She had neither arachnodactyly nor thromboembolic events. She was initially and successfully treated with pyridoxine $500 \mathrm{mg} /$ day, which was reduced to $100 \mathrm{mg} /$ day and then $50 \mathrm{mg} /$ day.

At age 24 years, she had a normal pregnancy giving birth to an unaffected child, without post-partum complications. At age 29 years, she had a male child by a different unrelated partner. The plasma total homocysteine (tHcy) in this child was elevated at $107 \mu \mathrm{mol} / \mathrm{l}(N=5-15)$. Fol- 
low-up of the mother between the ages of 29 and 48 years showed satisfactory metabolic control (plasma tHcy 21 $112 \mu \mathrm{mol} / \mathrm{l}$, plasma methionine $45-48 \mu \mathrm{mol} / \mathrm{l}$ ) with therapy including pyridoxine $50 \mathrm{mg} /$ day, folic acid $5 \mathrm{mg}$ /day, cyanocobalamin $50 \mu \mathrm{g} /$ day and an unrestricted diet. No new clinical events have occurred, despite the fact she was a mild smoker. Molecular study of the CBS gene showed the mutations c.374 G>A (R125Q) in exon 3 and c.671 $\mathrm{G}>\mathrm{T}(\mathrm{R} 224 \mathrm{~L})$ in exon 6.

The second child of our patient was seen at the age of 17 days for homocystinuria screening. His father had no family history of homocystinuria. At the age of 17 days, free Hcy was not detected but 8 months later plasma tHcy and methionine were 107 and $1999 \mu \mathrm{mol} / \mathrm{l}$, respectively. A methionine-restricted diet was started, with pyridoxine 50 $\mathrm{mg} /$ day and folic acid $5 \mathrm{mg} /$ day. Between the age of one and nine years, metabolic control was good with plasma tHcy less than 5-13 $\mu \mathrm{mol} / \mathrm{l}$, methionine 46-53 $\mu \mathrm{mol} / \mathrm{l}$, growth was normal and no lens dislocation was observed. The patient had no arachnodactyly, no bone deformities and his neurological development was normal. At age 10 years, betaine $3 \mathrm{~g}$ /day was started. From age 13 to 19 years, plasma tHcy and methionine mostly remained high, at 100-201 and 636-708 $\mu \mathrm{mol} / \mathrm{l}$ respectively, despite increasing doses of pyridoxine to $300 \mathrm{mg} /$ day, betaine to $4.5 \mathrm{~g} /$ day and adding cyanocobalamin $50 \mu \mathrm{g} /$ day. No clinical events were reported and eye examination remained normal despite suspected non-compliance with therapy. At age 19 years, his DEXA lumbar spine $Z$-score was -2.7. Molecular analysis of the CBS gene showed the mutations c374 G>A (R125Q) and c.689 insC, which predicts a frameshift and downstream stop codon.

\section{Discussion and conclusion}

For the mother, a low dose of pyridoxine was able to maintain a satisfactory plasma tHcy without dietary methionine restriction. This indicates that she had pyridoxine responsive homocystinuria. Patients homozygous for the R125Q mutation have been previously described as pyridoxine non-responsive [1] or partially pyridoxine responsive if associated with the severe phenotype [2]. Thus, the case of the patient's mother suggests that R125Q mutation in one copy, in association with another missense mutation (R224L), does not result in pyridoxine non-responsiveness. Moreover, we think that her severe phenotype was more related to late diagnosis than her genotype. Her son did not inherit her pyridoxine responsiveness as a high dose of pyridoxine was unable to significantly reduce plasma tHcy [3]. He carried a novel, severe and pathogenic mutation (c.689 insC) of the CBS gene, in association with the maternally inherited R125Q, which resulted in a pyridoxine non-responsive homocystinuria. It is also likely that, after a period of good metabolic control during childhood, he failed to maintain a methio- nine-restricted diet in the teenage years, a potential problem encountered in adolescence during the followup of many patients with inborn errors of metabolism [4]. In most patients, pyridoxine responsiveness is based on the presence of residual activity of mutant CBS, which have been closely linked to CBS mutations [5]. For example, the frequent G370S mutation, in one or two copies, appears to be incompatible with pyridoxine responsiveness, producing a severe phenotype [1]. Conversely, the I278T mutation usually confers pyridoxine responsiveness, whether in homozygotes or compound heterozygotes [6]. In the case presented here, the son has inherited a severe pyridoxine non-responsive mutation from his father who presumably was a heterozygous carrier of this mutant CBS allele. It has been shown that an identical CBS genotype does not always result in the same phenotype, even within a family, and although pyridoxine responsiveness is absolutely constant within sibships, the clinical phenotype is often not [5]. This indicates that non-heritable factors may influence the clinical expression of homocystinuria in genetically predisposed individuals.

Beyond the genotype-phenotype correlation, the homocystinuria described in this family shows that a maximal benefit from therapy may be expected when the disorder is detected in early infancy. Although it is generally recognized that pyridoxine responsive patients are more mildly affected than non-responsive patients, the cases reported here show that a methionine restriction diet started early can prevent or delay a number of important complications of CBS deficiency, in particular neurodevelopment and lens dislocation. This is consistent with previous data showing that patients carrying the G307S mutation seem to have moderate to severe phenotypes, except for those treated from birth [5]. Newborn screening and early treatment for phenylketonuria dramatically alters the clinical phenotype and our cases mirror this. We recommend that offspring of people with homocystinuria should be screened early in infancy and if positive, treated appropriately whether they have pyridoxine responsive or unresponsive disease.

\section{Competing interests}

The authors declare that they have no competing interests.

\section{Authors' contributions}

All of the authors have contributed to the writing of this manuscript, have been involved in subsequent revisions and have given final approval of the version to be published.

\section{Consent}

Written informed consent was obtained from the patients for publication of this case report. A copy of the written 
consent is available for review by the Editor-in-Chief of this journal.

\section{References}

I. Gaustadnes M, Wilcken B, Oliveriusova J, Mc Gill J, Fletcher J, Kraus JP, Wilcken DE: The molecular basis of cystathionine ?-synthase deficiency Australian patients: genotype-phenotype correlations and response to treatment. Hum Mutat 2002, 20:117-126.

2. Sebastio G, Sperandeo MP, Panico M, de Franchis R, Kraus JP, Andria $\mathrm{G}$ : The molecular basis of homocystinuria due cystathionine ?-synthase deficiency in Italian families, and report of four novel mutations. Am J Hum Genet 1995, 56:1324-1333.

3. Yap S, Naughten E: Homocystinuria due to cystathionine betasynthase deficiency in Ireland: 25 years' experience of a newborn screened and treated population with reference to clinical outcome and biochemical control. J Inherit Metab Dis 1998, 2I:738-747.

4. Enns GM, Packmann W: The adolescent with an inborn error of metabolism: medical issues and transition to adulthood. Adolesc Med 2002, 13:315-329.

5. Mudd SH, Levy HL, Kraus JP: Disorders of transulfuration. In The Metabolic and Molecular Basis of Inherited Disease Volume 2. 8th edition. Edited by: Scriver CR, Beaudet AL, Sly WS, Valle D. New York: McGraw-Hill; 200I:2007-2056.

6. Shih VE, Fringer JM, Mandell R, Kraus JP, Berry GT, Heidenrich RA, Korson MS, Levy HL, Ramesh V: missense mutation (I278T) in the cystathionine beta-synthase gene prevalent in pyridoxine-responsive homocystinuria and associated with mild clinical phenotype. Am J Hum Genet 1995, 57:34-39.

\section{Publish with Biomed Central and every scientist can read your work free of charge}

"BioMed Central will be the most significant development for disseminating the results of biomedical research in our lifetime. "

Sir Paul Nurse, Cancer Research UK

Your research papers will be:

- available free of charge to the entire biomedical community

- peer reviewed and published immediately upon acceptance

- cited in PubMed and archived on PubMed Central

- yours - you keep the copyright

Submit your manuscript here:

http://www.biomedcentral.com/info/publishing_adv.asp 